\title{
1 Surface modification of food processing and handling gloves for 2 enhanced food safety and hygiene
}

Jun Kyun Oh ${ }^{\text {a }}$,William Rapisand ${ }^{\mathrm{b}}$, Ming Zhang ${ }^{\mathrm{c}}$, Yagmur Yegin ${ }^{\mathrm{d}}$, Younjin Min ${ }^{\mathrm{c}}$, Alejandro Castillo ${ }^{\mathrm{e}}$, Luis Cisneros-Zevallos ${ }^{\mathrm{f}}$, Mustafa Akbulut ${ }^{\mathrm{a}, \mathrm{b}, *}$

${ }^{a}$ Department of Materials Science and Engineering, Texas A\&M University, College Station, TX 77843, USA

${ }^{\mathrm{b}}$ Artie McFerrin Department of Chemical Engineering, Texas A\&M University, College Station, TX 77843, USA

${ }^{\mathrm{c}}$ Department of Polymer Engineering, The University of Akron, Akron, OH 44325, USA

${ }^{\mathrm{d}}$ Department of Nutrition and Food Science, Texas A\&M University, College Station, TX 77843, USA

${ }^{\mathrm{e}}$ Department of Animal Science, Texas A\&M University, College Station, TX 77843, USA

${ }^{\mathrm{f}}$ Department of Horticultural Sciences, Texas A\&M University, College Station, TX 77843, USA

12 *Corresponding author. E-mail address: makbulut@tamu.edu (M. Akbulut).

\section{Abstract}

14 Gloves made of materials such as latex, nitrile, and polyethylene are the most common types of barriers used to

15 prevent cross-contamination and transmission of pathogenic bacteria in the food industry. In this study, we report a

16 surface modification approach involving "fluorinated silica nanoparticles" (FSNs) to improve the barrier properties

17 of disposable glove surfaces. The bacterial antiadhesive (antifouling) properties of the modified gloves were

18 evaluated with Salmonella Typhimurium LT2 and Staphylococcus aureus at bacterial concentrations of 8.6 to $9.0 \mathrm{log}$

$19 \mathrm{CFU} / \mathrm{mL}$ through the dip-inoculation approach. Bacterial attachment to glove surfaces were enumerated by the pour

20 plating method as well as direct counting via scanning electron microscopy (SEM). The bacterial populations of $S$.

21 Typhimurium LT2 and S. aureus on FSN-coated latex, nitrile and polyethylene gloves was reduced by 1 to $2 \log$

22 units in comparison to bare gloves.

23 Keywords: Food safety, Bacterial pathogen, Bacterial cross-contamination, Disposable gloves 


\section{Introduction}

Foodborne illnesses are a global concern as they lead to morbidity and mortality with increasing rates throughout the world (Akhtar et al., 2014; Shi and Zhu, 2009). Bacterial pathogens such as Salmonella spp., Escherichia coli, Campylobacter spp., Staphylococcus aureus, Listeria monocytogenes, and Bacillus cereus are some of the major causes of foodborne illnesses (Kirk et al., 2015; Tauxe et al., 2010). According to the U.S. Centers for Disease Control and Prevention report 2013, bacterial pathogens account for $70.7 \%$ of all foodborne illnesses for meat and poultry, $43.8 \%$ for dairy and eggs, $42.0 \%$ for grains and beans, $24.1 \%$ for fish and shellfish, and 22.3\% for produce (Painter et al., 2013). Bacterial pathogens can come into contact with food and food products at any stage of "food-preparation", i.e., harvesting, slaughtering, processing, handling, and storage (DeVita et al., 2007; Todd et al., 2007). While there are various procedures for effective disinfecting of food-contact surfaces and reducing other bacterial contaminants (Azlin-Hasim et al., 2015; Chang and Schneider, 2012; Lavoine et al., 2014; Nguyen and Yuk, 2013; Sung et al., 2014; Surowsky et al., 2015; Zhang et al., 2015), such disinfection could be rescinded due to possible mishandled after cleaning and sanitizing. Hence, it is a common practice to use gloves to handle food and food products after sanitation processes (Todd et al., 2010). From a food safety perspective, gloves serve for two purposes: (i) to reduce the possibility of cross-contamination from food to food and (ii) to eliminate the possibility of transmission of pathogenic bacteria from human hands to food.

While the use of gloves improves food safety and hygiene, and is desired for food processing and handling (Green et al., 2007), gloves are not completely problem-free. For instance, when glove surfaces come into contact with bacterial pathogens, bacterial adhesion occurs and the bacteria can subsequently form biofilm on these surfaces (Chmielewski and Frank, 2003). If formed, bacterial biofilms are particularly difficult to eliminate using hygienic practices such as physical washing (e.g., brushing, scrubbing, and sonication) and chemical treatments (e.g., alcohol-based disinfectant, chlorine-based sanitizer, and hydrogen peroxide-based solution), because bacteria are embedded in their own extracellular polymeric substances, which guard bacteria against external physical forces and chemical agents attack (Corcoran et al., 2014). Along these lines, Kaneko et al. (1999) have reported the occurrence of bacterial retention on glove surfaces and the possibility of glove-facilitated bacterial transport. Kotwal et al. (2014) found that transfer of Salmonella from porcine skins to thick latex, thin latex, and nitrile gloves 
55 can take place with the transfer rate of $40 \%, 27 \%$, and $19 \%$, respectively. Brar and Danyluk

56 (2013) reported that Salmonella can transfer from disposable latex gloves to tomatoes with a 57 transfer coefficient of $32 \%$ and $29 \%$ under wet and dry conditions, respectively, and from 58 tomatoes to gloves with a transfer coefficient of $37 \%$ and $39 \%$ under wet and dry conditions, 59 respectively. Overall, it is fair to claim that wearing gloves does not fully ensure the prevention 60 of cross-contamination and transmission of pathogenic bacteria during food processing and 61 handling.

62 To avoid the scenarios of cross-contamination and transmission of pathogenic bacteria 63 through glove surfaces, research efforts have been undertaken, in particular, towards 64 antimicrobial modifications of glove surfaces (Bastarrachea et al., 2015). Surface 65 functionalization with antimicrobial agents have been shown to be capable of preventing the spread of pathogenic bacteria. For example, antimicrobial agent (i.e., polyhexanide) generating glove surfaces (Leitgeb et al., 2013), glove surfaces impregnated with antiseptic dye (i.e., chlorhexidine) (Reitzel et al., 2009), and active release of disinfectant (i.e., chlorine dioxide) from the glove surfaces upon stimulation with moisture or light (Barza, 2004) have recently been reported. However, while gloves bearing antimicrobial agents reduce the bacterial growth and improve food safety, there are several issues that still need to be overcome such as the ineffectiveness against antimicrobial-resistant bacteria (Rasko and Sperandio, 2010), the development of antimicrobial resistance due to continuous exposure to antimicrobial agents (Levy and Marshall, 2004), and the long-term antimicrobial inefficiency (Puckett et al., 2010).

An alternative approach in reducing cross-contamination and transmission of pathogenic bacteria is the development of bacteria-repellent and antiadhesive (antifouling) surfaces. These surfaces reduce the bacterial adhesion to the surface of interest or repel bacteria from the surface of interest (Fadeeva et al., 2011; Oh et al., 2016). In other words, the goal is to minimize the number of bacteria reaching/attaching to the surface rather than disinfect bacteria reaching/attaching to the surface. Some examples of above-mentioned approaches for food safety applications can be enumerated, such as bacteria-repellent polyethylene glycol-coated surfaces (Zhang et al., 2014), zwitterionic surfaces (Cheng et al., 2007), functional biomimetic surfaces

84 responsive surfaces capable of surface deformation induced by shear forces (Shivapooja et al., 85 2013), and multilayer films containing heparin as an antiadhesive agent (Fu et al., 2005). While 
there are a number of studies reporting applications of these modifications on common foodcontact surfaces such as stainless steel (Yang et al., 2011), quartz glass (Oh et al., 2015), paper (Jin et al., 2012), polycarbonate (Ding et al., 2012), polytetrafluoroethylene (Epstein et al., 2012), and polyurethane (Park et al., 1998), the incorporation of gloves with bacterial antiadhesive properties have not been achieved yet.

Herein, we report the preparation of gloves with bacterial antiadhesive properties for food processing and handling applications using a scalable and facile dip-coating method. The coating has been applied on the three different types of gloves (i.e., latex, nitrile, and polyethylene) and achieved through the deposition and polymerization of "fluorinated silica nanoparticles" (FSNs) on glove surfaces. To evaluate the bacterial antiadhesive properties of the developed gloves, Gram-negative $S$. Typhimurium LT2 and Gram-positive $S$. aureus were utilized through an inoculation assay. The mechanical durability and chemical stability of FSN-coated gloves were investigated using scanning electron microscopy (SEM), nanotribometry, and attenuated total reflectance-Fourier transform infrared (ATR-FTIR) spectroscopy.

\section{Material and Methods}

\subsection{Preparation of glove surfaces}

Three different types of disposable gloves, i.e., latex (Polymed; Sempermed USA, Inc., Clearwater, FL, USA), nitrile (Upperhand; Maytex Co., Hayward, CA, USA), and polyethylene (Poly-D; Ansell, Richmond, Australia) commonly used glove materials for food processing and handling were prepared for the comparative studies. Gloves were first rinsed with Milli-Q water (resistivity $\geq 18.2 \mathrm{M} \Omega \cdot \mathrm{cm}$ ) produced by a Milli-Q water purification system (Milli-Q Advantage A10; EMD Millipore Corp., Billerica, MA, USA), and left to dry at room temperature $\left(23{ }^{\circ} \mathrm{C}\right)$.

\subsection{Fluorinated silica nanoparticles (FSNS)}

$100 \mathrm{mg}$ of silica ( $\mathrm{SiO}_{2}$; Sigma-Aldrich Co., St. Louis, MO, USA) nanoparticles with average diameter of $\sim 200 \mathrm{~nm}$ was suspended in $15 \mathrm{~mL}$ of hexane (Avantor Performance Materials, Inc., Center Valley, PA, USA), and then $5 \mathrm{mM}$ of trichloro $(1 \mathrm{H}, 1 \mathrm{H}, 2 \mathrm{H}, 2 \mathrm{H}-$ perfluorooctyl)silane (FDTS; Sigma-Aldrich Co., St. Louis, MO, USA) was added to obtain "fluorinated silica nanoparticles" (FSNs). FSNs were homogeneously suspended under sonication for 20 min using a probe ultrasonicator (SJIA-2000W; Ningbo Haishu Sklon 
115 Electronics Instruments Co., Ltd., Ningbo, Zhejiang, China). The FSN suspension was then left

116 for $1 \mathrm{~h}$ to allow the silane to fully react with silica nanoparticles.

\subsection{Dip-coating of glove surfaces}

FSNs were deposited on glove surfaces by dip-coating method (Fig. 1). Latex, nitrile, and polyethylene gloves were first cut into $1 \mathrm{~cm} \times 1 \mathrm{~cm}$ pieces. Gloves were then dipped into the FSN suspension. The method involved dipping gloves for $30 \mathrm{sec}$ and then allowing gloves to dry for $30 \mathrm{sec}$ five times over a 5-min period. FSN-coated gloves were then left to dry at room temperature for $24 \mathrm{~h}$.

\subsection{Surface characterization}

Surface morphology of glove surfaces were examined by scanning electron microscope (SEM, JSM-7500F; JEOL, Tokyo, Japan). Before SEM examination, the samples were coated with $8 \mathrm{~nm}$ of platinum/palladium $(\mathrm{Pt} / \mathrm{Pd})$ to minimize possible charging effects. The SEM was operated at an accelerating voltage of $1 \mathrm{kV}$ and emission current of $20 \mu \mathrm{A}$.

Topographic characteristics of glove surfaces were investigated by Dektak 3 stylus profilometer (Veeco Instruments, Inc., Plainview, NY, USA) with a scan length of $100 \mu \mathrm{m}$ to obtain surface roughness values. The samples were mounted on a glass slide by using a doublesided tape and then placed onto the stage to decrease data noise.

The chemical interactions between glove surfaces and FDTS-functionalized silica nanoparticles were characterized by attenuated total reflectance-Fourier transform infrared (ATR-FTIR) spectroscopy technique. ATR-FTIR spectra were measured using IRPrestige-21 (Shimadzu Corp., Kyoto, Japan) system and analyzed using IRsolution version 1.40 software (Shimadzu Corp., Kyoto, Japan).

In order to determine the wetting characteristics of glove surfaces, the static water contact angles were measured for the three different types of glove surfaces using the sessile drop technique. Reported contact angles on each surface were obtained by averaging five measurements at room temperature with the same droplet volume $(5 \mu \mathrm{L})$. Contact angles were analyzed using ImageJ software (National Institutes of Health, Bethesda, MD, USA) via LowBond Axisymmetric Drop Shape Analysis (LBADSA) plug-in (Stalder et al., 2010).

\subsection{Bacterial cultures}


Working cultures of Salmonella enterica subsp. enterica serovar Typhimurium str. LT2 (ATCC 700720) and Staphylococcus aureus (Food Microbiology Laboratory, Department of Animal Science, Texas A\&M University, College Station, TX) were obtained by scraping a portion of a culture on a tryptic soy agar (TSA; Becton, Dickinson and Co., Sparks, MD, USA) slant, and transferring to $9 \mathrm{~mL}$ of tryptic soy broth (TSB; Becton, Dickinson and Co., Sparks, MD, USA). These bacterial cultures were incubated aerobically without agitation at $37^{\circ} \mathrm{C}$ for 24 h. After $24 \mathrm{~h}$, a loopful of culture was transferred to fresh TSB, and reincubated at $37^{\circ} \mathrm{C}$ for $24 \mathrm{~h}$ twice consecutively. The final concentrations reached by $S$. Typhimurium LT2 and $S$. aureus in the growth medium ranged from 8.6 to $9.0 \log \mathrm{CFU} / \mathrm{mL}$.

\subsection{Surface inoculation}

For inoculation, bare and FSN-coated gloves were submerged in $9 \mathrm{~mL}$ of a bacterial suspension (8.6-9.0 $\log \mathrm{CFU} / \mathrm{mL})$ at room temperature for $1 \mathrm{~h}$ and $24 \mathrm{~h}$. The samples were gently removed from the bacterial suspension in a single vertical motion. After, the samples were rinsed in sterile Milli-Q water $(10 \mathrm{~mL})$ to dislodge loosely attached cells, and then transferred to sterile Petri dish for further bacterial adhesion assay. Bacteria that were not removed by Milli-Q water rinse were assumed to be attached. All experiments were carried out in an appropriate biological safety cabinet under sterile conditions. Inoculation experiments were replicated four times.

\subsection{Bacterial adhesion assay}

Bacterial attachment on glove surfaces with and without surface modification was assessed by plate count using the pour plating method and by direct enumeration on glove surfaces using SEM. For plate counts, gloves that were dip-inoculated for $1 \mathrm{~h}$ were vortex-mixed in $0.1 \%(\mathrm{w} / \mathrm{v})$ peptone water for $10 \mathrm{~min}$ to detach bacteria from the glove surfaces. After, serial dilutions of peptone water containing detached bacteria were made and plated on TSA plate. Bacterial densities were determined after $24 \mathrm{~h}$ of aerobic incubation at $37{ }^{\circ} \mathrm{C}$ and represented the density of bacteria that were attached onto the glove surfaces. All experiments were replicated four times.

The direct enumeration of attached bacteria on glove surfaces using SEM was conducted on gloves that were dipped in the inoculum for $1 \mathrm{~h}$ and $24 \mathrm{~h}$. Prior to SEM imaging, bacteria were inactivated by acrolein (Sigma-Aldrich Co., St. Louis, MO, USA) and a thin layer (10 nm) of 
$173 \mathrm{Pt} / \mathrm{Pd}$ film was deposited on the sample surfaces to ensure the electrical conductivity required by

174 SEM technique. For statistical reliability, at least ten different areas of $100 \mu \mathrm{m} \times 100 \mu \mathrm{m}$ (i.e., 175 entire scan area larger than $100,000 \mu \mathrm{m}^{2}$ ) from the three different samples of the same type of 176 glove surface were observed. As a direct counting approach, SEM micrographs were analyzed 177 using ImageJ to quantify the attachment of $S$. Typhimurium LT2 and S. aureus to glove surfaces.

178

179

180

181

182

183

184

185

186

187

188

189

190

191

192

193

194

195

196

197

198

199

200

201

\subsection{Mechanical robustness and chemical stability of glove coating}

Shear strength of glove coating was investigated using a nanotribometer (NTR; Anton Paar TriTec SA, Peseux, Switzerland). Produce-attached tip was used in the measurements. To prepare produce-attached tip, a spinach leaf cut into $3 \mathrm{~mm} \times 3 \mathrm{~mm}$ piece was attached to the tip by using an instant glue. All tests were conducted using a cantilever spring with normal and tangential stiffness of $55.9 \mathrm{~N} / \mathrm{m}$ and $36.8 \mathrm{~N} / \mathrm{m}$, respectively, at normal load of $10 \mathrm{mN}$, which provides a pressure of $\sim 5,000 \mathrm{~N} / \mathrm{m}^{2}$. These experimental conditions were chosen based on a previous report suggesting grip force for common produce, e.g., strawberry $\left(\sim 1,300 \mathrm{~N} / \mathrm{m}^{2}\right)$, carrot $\left(\sim 4,300 \mathrm{~N} / \mathrm{m}^{2}\right)$, and apple $\left(\sim 5,000 \mathrm{~N} / \mathrm{m}^{2}\right)$ (Pettersson et al., 2011). Before and after shearing experiments, the presence of wear and surface damage were investigated by SEM examination as well as measuring surface roughness of FSN-coated gloves using a profilometer.

Chemical stability of FSN-coated gloves was determined in deionized (DI) water as a function of time by monitoring if there is any chemical leaching from FSN-coated glove surfaces. This was achieved through analyzing aliquots collected from the samples (i.e., FSN-coated glove pieces submerged in DI water) using ATR-FTIR spectroscopy, with detection limit of $<1 \mathrm{ppm}$. While average time of wearing disposable glove is usually less than $4 \mathrm{~h}$, the measurements were conducted at submersion time of $24 \mathrm{~h}$, which present a sufficient condition.

\subsection{Statistical analysis}

The microbiological data were log-transformed prior to the statistical analysis. One-way and two-way analysis of variance (ANOVA) with Tukey's post hoc test was used to determine whether there were significant differences in the microbiological data between types of glove surfaces and types of bacteria, at a significance level of 0.05. All statistical analyses were performed using Analysis ToolPak-Excel (Microsoft Corp., Redmond, WA, USA) via statistical packages. 


\subsection{Characterization of FSN-coated glove surfaces}

Previous studies have shown that nano-scale and micro-scale surface roughness can influence bacterial adhesion (Cañas et al., 2012; Truong et al., 2010). When the length scale of surface roughness is larger than bacterial size, bacterial colonization can be enhanced because bacteria prefer to attach to concave surfaces (e.g., valleys, pits, edges, and depressions) due to increase in bacteria-surface total contact area (Wu et al., 2011). Hence, we characterized the surface topography of glove surfaces used in this study to better understand their bacterial adhesion behavior. SEM micrographs visually reveal nanostructures covering FSN-coated latex, nitrile, and polyethylene glove surfaces without interstices, as shown in Figs. 2a-c. To quantitatively compare the dimensional characteristics of bacterial size and surface roughness of gloves, the profilometer measurements were performed. The surface metrology measurements of FSN-coated latex, nitrile, and polyethylene gloves showed that the root-mean-square (RMS) roughness were $419 \pm 34 \mathrm{~nm}, 406 \pm 28 \mathrm{~nm}$, and $395 \pm 40 \mathrm{~nm}$, respectively. This means that surface roughness length scales of FSN-coated gloves were smaller than bacterial size (e.g., rod-shaped $S$. Typhimurium LT2 is 700-1500 nm wide by 2000-5000 nm long and spherical-shaped $S$. aureus is $600-1000 \mathrm{~nm}$ in diameter), thereby inhibiting the physical attachment such as penetration and trapping of bacteria into FSN-coated glove surfaces. Moreover, surface roughness of FSN-coated gloves meets the specific surface roughness value $(\leq 800 \mathrm{~nm})$ for proper hygienic design criteria for food-contact surfaces (Flint et al., 2000).

For the chemical modification of glove surfaces, fluorinated silane compound is selected due to its high affinity to silica (Vansant et al., 1995). Also, trifluoromethyl (-CF 3 ) functional groups are preferred over other nonpolar functional groups, because surface energy $(\gamma)$ decreases as hydrogen $(\mathrm{H})$ atoms are replaced with fluorine $(\mathrm{F})$ atoms in the following orders: $-\mathrm{CH}_{2}>-\mathrm{CH}_{3}$ $>-\mathrm{CF}_{2}>-\mathrm{CF}_{2} \mathrm{H}>-\mathrm{CF}_{3}$ (Hare et al., 1954). While bacteria can adhere on both hydrophilic and hydrophobic surfaces, it is known that bacterial attachment tends to occur significantly more on hydrophilic surfaces (Boks et al., 2008). Hence, we used trifluoromethyl functional groups to coat glove surfaces in order to reduce the intermolecular interactions between bacteria and surfaces. The presence of trifluoromethyl groups on glove surfaces was confirmed by ATR-FTIR spectroscopy analysis for all three different types of gloves (Fig. 3). To be specific, there was a 
232 peak at $\sim 1050 \mathrm{~cm}^{-1}$, corresponding to C-F stretching (Zeitler and Brown, 1957), for each glove 233 surface upon dip-coating.

234 Surface topography and chemical properties can act synergistically and influence the ability 235 of water dispersing bacteria to come in contact with surfaces in a non-linear fashion by creating 236 air-pockets (Lorenzetti et al., 2015). As such, we also studied the wetting characteristics of 237 gloves surfaces with water. Figs. 3b-g compare the contact angle of water droplets on bare and 238 FSN-coated glove surfaces. The static water contact angle measurements revealed that bare latex $239\left(\theta=126.7^{\circ} \pm 1.4^{\circ}\right)$, nitrile $\left(\theta=97.2^{\circ} \pm 0.4^{\circ}\right)$, and polyethylene $\left(\theta=90.9^{\circ} \pm 0.5^{\circ}\right)$ gloves were 240 hydrophobic. On the other hand, their FSN-coated versions were superhydrophobic with a 241 contact angle of $\theta=162.5^{\circ} \pm 0.7^{\circ}$ (latex), $\theta=162.7^{\circ} \pm 1.1^{\circ}$ (nitrile), and $\theta=163.9^{\circ} \pm 0.6^{\circ}$ 242 (polyethylene). Superhydrophobic surfaces are well-known as having self-cleaning properties 243 (often termed the "lotus effect"), which is beneficial for reducing bacterial adhesion (Fürstner et 244 al., 2005; Zhang et al., 2013).

\subsection{Bacterial attachment to FSN-coated glove surfaces characterized by plating counting}

After preparing and fully characterizing interfacial properties of the modified glove surfaces, we compared the bacterial attachment behavior on such surfaces with that on bare glove surfaces. Fig. 4a shows the plate count results of the three different types of gloves, following inoculation and attachment of Gram-negative $S$. Typhimurium LT2. The mean populations of bacteria attached on bare latex, nitrile, and polyethylene glove surfaces were $5.3 \pm 0.1 \log \mathrm{CFU} / \mathrm{mL}, 5.3 \pm$ $0.1 \log \mathrm{CFU} / \mathrm{mL}$, and $5.1 \pm 0.1 \log \mathrm{CFU} / \mathrm{mL}$, respectively, indicating that these surfaces supported bacterial attachment. When latex, nitrile, and polyethylene gloves were modified with FSNs to achieve a superhydrophobic character, bacterial attachment decreased, as indicated by the mean bacterial populations of $3.4 \pm 0.2 \log \mathrm{CFU} / \mathrm{mL}, 3.4 \pm 0.1 \log \mathrm{CFU} / \mathrm{mL}$, and $3.3 \pm 0.1$ $\log \mathrm{CFU} / \mathrm{mL}$, respectively, corresponding to $>98.2 \%$ in bacterial attachment. One-way ANOVA analysis showed the difference in the adhesion of $S$. Typhimurium LT2 with respect to the presence or absence of coating was statistically significant $(p<0.05)$.

The above observed trends also took place for Gram-positive bacteria, as observed in the plating experiments using $S$. aureus. Fig. $4 \mathrm{~b}$ graph shows the plate count results of $S$. aureus attachment on the three different types of gloves. Bare latex, nitrile, and polyethylene glove surfaces yielded mean densities of $5.5 \pm 0.1 \log \mathrm{CFU} / \mathrm{mL}, 5.4 \pm 0.1 \log \mathrm{CFU} / \mathrm{mL}$, and $5.3 \pm 0.1$ 
$262 \log \mathrm{CFU} / \mathrm{mL}$, respectively. In contrast, superhydrophobic FSN-coated latex, nitrile, and 263 polyethylene gloves had a reduced the number of bacteria, with mean densities of $3.5 \pm 0.2 \log$ $264 \mathrm{CFU} / \mathrm{mL}, 3.5 \pm 0.2 \log \mathrm{CFU} / \mathrm{mL}$, and $3.2 \pm 0.2 \log \mathrm{CFU} / \mathrm{mL}$, respectively, which corresponds to $265>98.5 \%$ reduction. According to one-way ANOVA analysis, the difference in the number of $S$. 266 aureus with respect to the presence or absence of coating was statistically significant $(p<0.05)$. 267 Overall, plating studies showed that the number of $S$. Typhimurium LT2 and $S$. aureus with the 268 use of FSN coating on gloves decreased by 1 to $2 \log \mathrm{CFU} / \mathrm{mL}$ on them. The comparison of 269 microbiological data on the three different types of glove surfaces with respect to types of 270 bacteria via two-way ANOVA analysis indicated that the attachment behavior of $S$. Typhimurium 271 LT2 and $S$. aureus to glove surfaces were not statistically significant $(p \geq 0.05)$, indicating a 272 similar reduction behavior for all types of gloves upon FSN coating.

\section{3}

274

275

\subsection{Bacterial attachment to FSN-coated glove surfaces characterized by SEM}

In addition to the pour plating method, SEM was also used to enumerate bacteria on glove surfaces to gain insight into the distribution and localization of bacteria on these surfaces. Fig. 5 shows the SEM micrographs of $S$. Typhimurium LT2 attached on the three different types of glove surfaces upon $1 \mathrm{~h}$ and $24 \mathrm{~h}$ inoculation. After $1 \mathrm{~h}$ exposure to bacteria, bacterial attachment to bare latex, nitrile, and polyethylene gloves resulted in mean densities of $4.1 \pm 0.2 \log$ cells $/ \mathrm{mm}^{2}, 4.0 \pm 0.2 \log$ cells $/ \mathrm{mm}^{2}$, and $4.0 \pm 0.1 \log$ cells $/ \mathrm{mm}^{2}$, respectively (Figs. 5a-c). Inoculation of FSN-coated latex, nitrile, and polyethylene gloves resulted in mean densities of $2.3 \pm 0.1 \log$ cells $/ \mathrm{mm}^{2}, 2.2 \pm 0.0 \log$ cells $/ \mathrm{mm}^{2}$, and $2.3 \pm 0.2 \log$ cells $/ \mathrm{mm}^{2}$, respectively. (Figs. $5 \mathrm{~d}-\mathrm{f}$ ), which corresponds to $>97.7 \%$ reduction in bacterial attachment in comparison to bare gloves. After $24 \mathrm{~h}$ exposure to bacteria, bacterial attachment to bare latex, nitrile, and polyethylene gloves resulted in mean densities of $4.9 \pm 0.1 \log$ cells $/ \mathrm{mm}^{2}, 5.1 \pm 0.1 \log$ cells $/ \mathrm{mm}^{2}$, and $5.0 \pm 0.0 \log$ cells $/ \mathrm{mm}^{2}$, respectively (Figs. $5 \mathrm{~g}-\mathrm{i}$ ). Inoculation of FSN-coated latex, nitrile, and polyethylene gloves resulted in mean densities of $2.7 \pm 0.2 \log$ cells $/ \mathrm{mm}^{2}, 2.6 \pm 0.2$ $\log$ cells $/ \mathrm{mm}^{2}$, and $2.6 \pm 0.2 \mathrm{log}$ cells $/ \mathrm{mm}^{2}$, respectively. (Figs. $5 \mathrm{j}-1$ ), which corresponds to $>99.3 \%$ reduction in bacterial attachment in comparison to bare gloves. In essence, bacterial attachment to superhydrophobic FSN-coated gloves was much less than bare gloves, with reduced the number of $S$. Typhimurium LT2 by 1 to $2 \log$ units.

We also enumerated the attachment of $S$. aureus to each glove surface using the same 
292 inoculation conditions. Fig. 6 shows the SEM micrographs of latex, nitrile, and polyethylene 293 glove surfaces after $1 \mathrm{~h}$ and $24 \mathrm{~h}$ inoculation with $S$. aureus. After $1 \mathrm{~h}$ exposure to bacteria, a 294 mean density of bacteria present on bare latex, nitrile, and polyethylene gloves was $4.3 \pm 0.3 \log$ 295 cells $/ \mathrm{mm}^{2}, 4.2 \pm 0.2 \log$ cells $/ \mathrm{mm}^{2}$, and $4.3 \pm 0.1 \mathrm{log}$ cells $/ \mathrm{mm}^{2}$, respectively (Figs. 6a-c). 296 Inoculation of FSN-coated gloves resulted in mean densities of $2.4 \pm 0.0 \log$ cells $/ \mathrm{mm}^{2}, 2.5 \pm 0.2$ $297 \log$ cells $/ \mathrm{mm}^{2}$, and $2.5 \pm 0.2 \log$ cells $/ \mathrm{mm}^{2}$, respectively (Figs. 6d-f), which corresponds to 298 reduction in bacterial attachment by $>98.1 \%$ upon $1 \mathrm{~h}$ inoculation. After $24 \mathrm{~h}$ exposure to 299 bacteria, a mean density of bacteria present on bare latex, nitrile, and polyethylene gloves was $3004.9 \pm 0.2 \log$ cells $/ \mathrm{mm}^{2}, 4.9 \pm 0.3 \log$ cells $/ \mathrm{mm}^{2}$, and $5.1 \pm 0.1 \log$ cells $/ \mathrm{mm}^{2}$, respectively (Figs. 301 6g-i). Inoculation of FSN-coated latex, nitrile, and polyethylene gloves resulted in mean 302 densities of $2.7 \pm 0.3 \log$ cells $/ \mathrm{mm}^{2}, 2.9 \pm 0.2 \log$ cells $/ \mathrm{mm}^{2}$, and $2.9 \pm 0.2 \log$ cells $/ \mathrm{mm}^{2}$, 303 respectively (Figs. 6j-1). These data indicate that bacterial attachment was reduced by $>99.1 \%$ on 304 FSN-coated gloves compared to bare gloves upon $24 \mathrm{~h}$ inoculation.

305 Both plate count and SEM results demonstrated that superhydrophobic FSN-coated gloves 306 effectively inhibit bacterial attachment in comparison to bare gloves. Even with $24 \mathrm{~h}$ exposure to 307 bacterial suspensions, $S$. Typhimurium LT2 and S. aureus were less likely to reside on FSN308 coated glove surfaces. This phenomenon can be explained in terms of the wetting transition from 309 the Wenzel state to the Cassie-Baxter state due to FSN coating on the surfaces (Chen et al., 2012). 310 The transition into the Cassie-Baxter state implies that air-pockets form when water comes into 311 contact with glove surfaces, thereby decreasing effective (real) contact area between glove 312 surfaces and water containing bacterial pathogens (Crick et al., 2011). Our results can also be 313 explained in terms of hydrophobic effect (Chandler, 2005; Neu, 1996). Prior studies showed that 314 the water contact angle of $S$. Typhimurium LT2 and $S$. aureus layer collected on a filter ranged 315 from $15^{\circ}$ to $27^{\circ}$ (Dickson and Koohmaraie, 1989; van Loosdrecht et al., 1987). When these 316 bacteria with highly hydrophilic cell surfaces come into contact with nonpolar surfaces, 317 unfavorable intermolecular interactions arise, inhibiting bacterial attachment.

\subsection{Mechanical robustness and chemical stability of FSN-coated gloves}

Maintaining superhydrophobic properties of FSN-coated gloves are important to ensure bacterial antiadhesion performance of the coating during usage. In this context, we evaluated shear strength of FSN coating on gloves to determine mechanical durability of FSN-coated 
gloves (Fig. 7a). All shearing experiments were carried out under the normal load of $10 \mathrm{mN}$ for 32310 cycles using a produce-attached tip. As shown in Figs. 7b-g, FSN-coated glove surfaces 324 showed similar surface morphology before and after shearing with a produce-attached tip, 325 indicating practical mechanical durability. Furthermore, difference in surface roughness values 326 before and after shearing were measured using a profilometer. Before shearing, RMS roughness 327 of FSN-coated latex, nitrile, and polyethylene glove surfaces were $419 \pm 34 \mathrm{~nm}, 406 \pm 28 \mathrm{~nm}$, 328 and $395 \pm 40 \mathrm{~nm}$, respectively. Similar results were obtained after shearing as well: $426 \pm 42 \mathrm{~nm}$, $329405 \pm 47 \mathrm{~nm}$, and $403 \pm 43 \mathrm{~nm}$, respectively, which indicates mechanical durability of FSN330 coated gloves.

331 The potential toxicity, if any, of the developed gloves are directly related to the ability to 332 leach chemicals from their FDTS-functionalized silica nanoparticle surfaces through detachment, 333 degradation, or decomposition of fluoro groups. Hence, we investigated chemical stability of 334 FSN-coated gloves in DI water as a function of time using ATR-FTIR spectroscopy. Unbound 335 FDTS molecules had symmetric and asymmetric C-F stretching peak near $1050 \mathrm{~cm}^{-1}$. The spectroscopic analysis revealed that FSN-coated gloves submerged in DI water had no chemical leaching and present the absences of free chemicals within the detection limit of $1 \mathrm{ppm}$ at least in a 24-hour period (Fig. 8).

\section{9}

\section{Conclusions}

Cross-contamination and transmission of pathogenic bacteria during food processing and handling has become an issue throughout the world. Gloves are the most commonly used protective equipment or barriers against bacterial contamination. However, recent studies have pointed out that the use of gloves, while improving food safety to some extent, may be insufficient to completely prevent the spread of pathogenic bacteria. Herein, we report surface modification of latex, nitrile, and polyethylene gloves with "fluorinated silica nanoparticles" (FSNs) to limit bacterial adhesion. This in turn should reduce the risk of potential crosscontamination and transmission of pathogenic bacteria associated with glove surfaces. The bacterial antiadhesive (antifouling) properties of FSN-coated gloves was confirmed against Gram-negative $S$. Typhimurium LT2 and Gram-positive $S$. aureus, with significantly greater (1-2 $\log$ units) bacterial populations on bare gloves than on modified gloves, via plate counting and direct SEM visualization after dip-inoculation. The ability of FSN-coated gloves to inhibit 
bacterial attachment is attributed to their nanotextured morphology and low surface energy, the synergistic combination of which leads to superhydrophobic surfaces. Superhydrophobicity translates into a reduced effective (real) contact between glove surfaces and water containing bacterial pathogens, decreasing the probability of bacteria to reach glove surfaces. Overall, the promising bacterial antiadhesive properties of FSN-coated gloves as well as a scalable and facile nature of the application method (i.e., dip-coating) can offer a simple solution for enhancing microbiological food safety and hygiene of disposable gloves used in the food industry.

\section{Acknowledgements}

This project was supported by the Agriculture and Food Research Initiative (AFRI) Competitive Grant No. 2011-67017-30028 from the National Institute of Food and Agriculture (NIFA), U.S. Department of Agriculture (USDA) to M. A., J. K. O., and L. C.-Z., and by the NSF Grant No. 1511626 to M. Z. and Y. M.

\section{References}

Akhtar, S., Sarker, M.R., \& Hossain, A. (2014). Microbiological food safety: A dilemma of developing societies. Critical Reviews in Microbiology, 40(4), 348-359. doi:10.3109/1040841X.2012.742036

Azlin-Hasim, S., Cruz-Romero, M.C., Ghoshal, T., Morris, M.A., Cummins, E., \& Kerry, J.P. (2015). Application of silver nanodots for potential use in antimicrobial packaging applications. Innovative Food Science \& Emerging Technologies, 27, 136-143. doi:10.1016/j.ifset.2014.10.012

Barza, M. (2004). Efficacy and tolerability of $\mathrm{ClO}_{2}$-generating gloves. Clinical Infectious Diseases, 38(6), 857-863. doi:10.1086/382535

Bastarrachea, L.J., Denis-Rohr, A., \& Goddard, J.M. (2015). Antimicrobial food equipment coatings: Applications and challenges. Annual Review of Food Science and Technology, 6(1), 97-118. doi:10.1146/annurev-food022814-015453

Bixler, G.D., \& Bhushan, B. (2014). Rice- and butterfly-wing effect inspired self-cleaning and low drag micro/nanopatterned surfaces in water, oil, and air flow. Nanoscale, 6(1), 76-96. doi:10.1039/C3NR04755E

Boks, N.P., Norde, W., van der Mei, H.C., \& Busscher, H.J. (2008). Forces involved in bacterial adhesion to hydrophilic and hydrophobic surfaces. Microbiology, 154(10), 3122-3133. doi:10.1099/mic.0.2008/018622-0

Brar, P.K., \& Danyluk, M.D. (2013). Salmonella transfer potential during hand harvesting of tomatoes under laboratory conditions. Journal of Food Protection, 76(8), 1342-1349. doi:10.4315/0362-028X.JFP-13-048

Cañas, N., Kamperman, M., Völker, B., Kroner, E., McMeeking, R.M., \& Arzt, E. (2012). Effect of nano- and micro-roughness on adhesion of bioinspired micropatterned surfaces. Acta Biomaterialia, 8(1), 282-288. doi:10.1016/j.actbio.2011.08.028

Chandler, D. (2005). Interfaces and the driving force of hydrophobic assembly. Nature, 437(7059), 640-7. doi:10.1038/nature04162

Chang, A.S., \& Schneider, K.R. (2012). Evaluation of overhead spray-applied sanitizers for the reduction of Salmonella on tomato surfaces. Journal of Food Science, 77(1), M65-M69. doi:10.1111/j.17503841.2011.02486.x 
Chen, L., Yang, G., \& Wang, S. (2012). Air-grid surface patterning provided by superhydrophobic surfaces. Small, 8(7), 962-965. doi:10.1002/smll.201102345

Cheng, G., Zhang, Z., Chen, S., Bryers, J.D., \& Jiang, S. (2007). Inhibition of bacterial adhesion and biofilm formation on zwitterionic surfaces. Biomaterials, 28(29), 4192-4199. doi:10.1016/j.biomaterials.2007.05.041

Chmielewski, R.A.N., \& Frank, J.F. (2003). Biofilm formation and control in food processing facilities. Comprehensive Reviews in Food Science and Food Safety, 2(1), 22-32. doi:10.1111/j.15414337.2003.tb00012.x

Corcoran, M., Morris, D., De Lappe, N., O’Connor, J., Lalor, P., Dockery, P., \& Cormican, M. (2014). Commonly used disinfectants fail to eradicate Salmonella enterica biofilms from food contact surface materials. Applied and Environmental Microbiology, 80(4), 1507-14. doi:10.1128/AEM.03109-13

Crick, C.R., Ismail, S., Pratten, J., \& Parkin, I.P. (2011). An investigation into bacterial attachment to an elastomeric superhydrophobic surface prepared via aerosol assisted deposition. Thin Solid Films, 519(11), 3722-3727. doi:10.1016/j.tsf.2011.01.282

DeVita, M.D., Wadhera, R.K., Theis, M.L., \& Ingham, S.C. (2007). Assessing the potential of Streptococcus pyogenes and Staphylococcus aureus transfer to foods and customers via a survey of hands, hand-contact surfaces and food-contact surfaces at foodservice facilities. Journal of Foodservice, 18(2), 76-79. doi:10.1111/j.1745-4506.2007.00049.x

Dickson, J.S., \& Koohmaraie, M. (1989). Cell surface charge characteristics and their relationship to bacterial attachment to meat surfaces. Applied and Environmental Microbiology, 55(4), 832-6. Retrieved from http://www.ncbi.nlm.nih.gov/pubmed/2499255

Ding, X., Yang, C., Lim, T. P., Hsu, L.Y., Engler, A.C., Hedrick, J.L., \& Yang, Y.-Y. (2012). Antibacterial and antifouling catheter coatings using surface grafted PEG-b-cationic polycarbonate diblock copolymers. Biomaterials, 33(28), 6593-6603. doi:10.1016/j.biomaterials.2012.06.001

Epstein, A.K., Wong, T.-S., Belisle, R.A., Boggs, E.M., \& Aizenberg, J. (2012). Liquid-infused structured surfaces with exceptional anti-biofouling performance. Proceedings of the National Academy of Sciences, 109(33), 13182-13187. doi:10.1073/pnas.1201973109

Fadeeva, E., Truong, V.K., Stiesch, M., Chichkov, B.N., Crawford, R.J., Wang, J., \& Ivanova, E.P. (2011). Bacterial retention on superhydrophobic titanium surfaces fabricated by femtosecond laser ablation. Langmuir, 27(6), 3012-3019. doi:10.1021/la104607g

Flint, S.H., Brooks, J.D., \& Bremer, P.J. (2000). Properties of the stainless steel substrate, influencing the adhesion of thermo-resistant streptococci. Journal of Food Engineering, 43(4), 235-242. doi:10.1016/S02608774(99)00157-0

Fu, J., Ji, J., Yuan, W., \& Shen, J. (2005). Construction of anti-adhesive and antibacterial multilayer films via layerby-layer assembly of heparin and chitosan. Biomaterials, 26(33), 6684-6692. doi:10.1016/j.biomaterials.2005.04.034

Fürstner, R., Barthlott, W., Neinhuis, C., \& Walzel, P. (2005). Wetting and self-cleaning properties of artificial superhydrophobic surfaces. Langmuir, 21(3), 956-961. doi:10.1021/la0401011

Green, L.R., Radke, V., Mason, R., Bushnell, L., Reimann, D.W., Mack, J.C., Motsinger, M.D., Stigger, T., \& Selman, C.A. (2007). Factors related to food worker hand hygiene practices. Journal of Food Protection, 70(3), 661-6. Retrieved from http://www.ncbi.nlm.nih.gov/pubmed/17388056

Hare, E.F., Shafrin, E.G., \& Zisman, W.A. (1954). Properties of films of adsorbed fluorinated acids. The Journal of Physical Chemistry, 58(3), 236-239. doi:10.1021/j150513a011

Jin, C., Jiang, Y., Niu, T., \& Huang, J. (2012). Cellulose-based material with amphiphobicity to inhibit bacterial adhesion by surface modification. Journal of Materials Chemistry, 22(25), 12562. doi:10.1039/c2jm31750h

Kaneko, K., Hayashidani, H., Takahashi, K., Shiraki, Y., Limawongpranee, S., \& Ogawa, M. (1999). Bacterial contamination in the environment of food factories processing ready-to-eat fresh vegetables. Journal of Food 
Protection, 62(7), 800-4. Retrieved from http://www.ncbi.nlm.nih.gov/pubmed/10419276

Kirk, M.D., Pires, S.M., Black, R.E., Caipo, M., Crump, J.A., Devleesschauwer, B., Döpfer, D., Fazil, A., FischerWalker, C.L., Hald, T., Hall, A.J., Keddy, K.H., Lake, R.J., Lanata, C.F., Torgerson, P.R., Havelaar, A.H., \& Angulo, F.J. (2015). World Health Organization estimates of the global and regional disease burden of 22 foodborne bacterial, protozoal, and viral diseases, 2010: A data synthesis. PLOS Medicine, 12(12), e1001921. doi:10.1371/journal.pmed.1001921

Kotwal, G., Lee, C.-C., Kang, W., \& Cannon, J. (2014). Comparative study of human finger pads and porcine skins used to quantify cross-contamination by norovirus and Salmonella during glove application and food handling. In 2014 IAFP Annual Meeting. Retrieved from https://iafp.confex.com/iafp/2014/webprogram/Paper6835.html

Lavoine, N., Givord, C., Tabary, N., Desloges, I., Martel, B., \& Bras, J. (2014). Elaboration of a new antibacterial bio-nano-material for food-packaging by synergistic action of cyclodextrin and microfibrillated cellulose. Innovative Food Science \& Emerging Technologies, 26, 330-340. doi:10.1016/j.ifset.2014.06.006

Leitgeb, J., Schuster, R., Eng, A.-H., Yee, B.-N., Teh, Y.-P., Dosch, V., \& Assadian, O. (2013). In-vitro experimental evaluation of skin-to-surface recovery of four bacterial species by antibacterial and nonantibacterial medical examination gloves. Antimicrobial Resistance and Infection Control, $2(1), 27$. doi:10.1186/2047-2994-2-27

Levy, S.B., \& Marshall, B. (2004). Antibacterial resistance worldwide: Causes, challenges and responses. Nature Medicine, 10(12s), S122-S129. doi:10.1038/nm1145

Lorenzetti, M., Dogša, I., Stošicki, T., Stopar, D., Kalin, M., Kobe, S., \& Novak, S. (2015). The influence of surface modification on bacterial adhesion to titanium-based substrates. ACS Applied Materials \& Interfaces, 7(3), 1644-1651. doi:10.1021/am507148n

Neu, T.R. (1996). Significance of bacterial surface-active compounds in interaction of bacteria with interfaces. Microbiological Reviews, 60(1), 151-66. Retrieved from http://www.ncbi.nlm.nih.gov/pubmed/8852899

Nguyen, H.D.N., \& Yuk, H.-G. (2013). Changes in resistance of Salmonella Typhimurium biofilms formed under various conditions to industrial sanitizers. Food Control, 29(1), 236-240. doi:10.1016/j.foodcont.2012.06.006

Oh, J.K., Kohli, N., Zhang, Y., Min, Y., Jayaraman, A., Cisneros-Zevallos, L., \& Akbulut, M. (2016). Nanoporous aerogel as a bacteria repelling hygienic material for healthcare environment. Nanotechnology, $27(8), 085705$. doi:10.1088/0957-4484/27/8/085705

Oh, J.K., Lu, X., Min, Y., Cisneros-Zevallos, L., \& Akbulut, M. (2015). Bacterially antiadhesive, optically transparent surfaces inspired from rice leaves. ACS Applied Materials \& Interfaces, 7(34), 19274-19281. doi:10.1021/acsami.5b05198

Oh, J.K., Perez, K., Kohli, N., Kara, V., Li, J., Min, Y., Castillo, A., Taylor, M., Jayaraman, A., Cisneros-Zevallos, L., \& Akbulut, M. (2015). Hydrophobically-modified silica aerogels: Novel food-contact surfaces with bacterial anti-adhesion properties. Food Control, 52, 132-141. doi:10.1016/j.foodcont.2014.12.029

Painter, J.A., Hoekstra, R.M., Ayers, T., Tauxe, R.V., Braden, C.R., Angulo, F.J., \& Griffin, P.M. (2013). Attribution of foodborne illnesses, hospitalizations, and deaths to food commodities by using outbreak data, United States, 1998-2008. Emerging Infectious Diseases, 19(3), 407-415. doi:10.3201/eid1903.111866

Park, K.D., Kim, Y.S., Han, D.K., Kim, Y.H., Lee, E.H.B., Suh, H., \& Choi, K.S. (1998). Bacterial adhesion on PEG modified polyurethane surfaces. Biomaterials, 19(7-9), 851-859. doi:10.1016/S0142-9612(97)00245-7

Pettersson, A., Ohlsson, T., Davis, S., Gray, J.O., \& Dodd, T.J. (2011). A hygienically designed force gripper for flexible handling of variable and easily damaged natural food products. Innovative Food Science \& Emerging Technologies, 12(3), 344-351. doi:10.1016/j.ifset.2011.03.002

Puckett, S.D., Taylor, E., Raimondo, T., \& Webster, T.J. (2010). The relationship between the nanostructure of titanium surfaces and bacterial attachment. Biomaterials, 31(4), $706-713$. doi:10.1016/j.biomaterials.2009.09.081

Rasko, D.A., \& Sperandio, V. (2010). Anti-virulence strategies to combat bacteria-mediated disease. Nature 
Reitzel, R.A., Dvorak, T.L., Hachem, R.Y., Fang, X., Jiang, Y., \& Raad, I. (2009). Efficacy of novel antimicrobial gloves impregnated with antiseptic dyes in preventing the adherence of multidrug-resistant nosocomial pathogens. American Journal of Infection Control, 37(4), 294-300. doi:10.1016/j.ajic.2008.07.003

Shi, X., \& Zhu, X. (2009). Biofilm formation and food safety in food industries. Trends in Food Science \& Technology, 20(9), 407-413. doi:10.1016/j.tifs.2009.01.054

Shivapooja, P., Wang, Q., Orihuela, B., Rittschof, D., López, G.P., \& Zhao, X. (2013). Bioinspired surfaces with dynamic topography for active control of biofouling. Advanced Materials, 25(10), 1430-1434. doi:10.1002/adma.201203374

Stalder, A.F., Melchior, T., Müller, M., Sage, D., Blu, T., \& Unser, M. (2010). Low-bond axisymmetric drop shape analysis for surface tension and contact angle measurements of sessile drops. Colloids and Surfaces A: Physicochemical and Engineering Aspects, 364(1-3), 72-81. doi:10.1016/j.colsurfa.2010.04.040

Sung, S.-Y., Sin, L.T., Tee, T.-T., Bee, S.-T., \& Rahmat, A.R. (2014). Effects of Allium sativum essence oil as antimicrobial agent for food packaging plastic film. Innovative Food Science \& Emerging Technologies, 26, 406-414. doi:10.1016/j.ifset.2014.05.009

Surowsky, B., Schlüter, O., \& Knorr, D. (2015). Interactions of non-thermal atmospheric pressure plasma with solid and liquid food systems: A review. Food Engineering Reviews, 7(2), 82-108. doi:10.1007/s12393-014-9088-5

Tauxe, R.V., Doyle, M.P., Kuchenmüller, T., Schlundt, J., \& Stein, C.E. (2010). Evolving public health approaches to the global challenge of foodborne infections. International Journal of Food Microbiology, 139, S16-S28. doi:10.1016/j.ijfoodmicro.2009.10.014

Todd, E.C.D., Greig, J.D., Bartleson, C.A., \& Michaels, B.S. (2007). Outbreaks where food workers have been implicated in the spread of foodborne disease. Part 3. Factors contributing to outbreaks and description of outbreak categories. Journal of Food Protection, 70(9), 2199-217. Retrieved from http://www.ncbi.nlm.nih.gov/pubmed/17900100

Todd, E.C.D., Michaels, B.S., Greig, J.D., Smith, D., \& Bartleson, C.A. (2010). Outbreaks where food workers have been implicated in the spread of foodborne disease. Part 8. Gloves as barriers to prevent contamination of food by workers. Journal of Food Protection, 73(9), 1762-73. Retrieved from http://www.ncbi.nlm.nih.gov/pubmed/20828485

Truong, V.K., Lapovok, R., Estrin, Y.S., Rundell, S., Wang, J. Y., Fluke, C.J., Crawford, R.J., \& Ivanova, E.P. (2010). The influence of nano-scale surface roughness on bacterial adhesion to ultrafine-grained titanium. Biomaterials, 31(13), 3674-3683. doi:10.1016/j.biomaterials.2010.01.071

van Loosdrecht, M.C., Lyklema, J., Norde, W., Schraa, G., \& Zehnder, A.J. (1987). The role of bacterial cell wall hydrophobicity in adhesion. Applied and Environmental Microbiology, 53(8), 1893-7. Retrieved from http://www.ncbi.nlm.nih.gov/pubmed/2444158

Vansant, E.F., Voort, P. Van Der, \& Vrancken, K.C. (1995). Chapter 1 Silica: Preparation and properties. In Studies in Surface Science and Catalysis (Vol. 93, pp. 3-30). doi:10.1016/S0167-2991(06)81509-0

Wu, Y., Zitelli, J.P., TenHuisen, K.S., Yu, X., \& Libera, M.R. (2011). Differential response of Staphylococci and osteoblasts to varying titanium surface roughness. Biomaterials, 32(4), 951-960. doi:10.1016/j.biomaterials.2010.10.001

Yang, W. J., Cai, T., Neoh, K.-G., Kang, E.-T., Dickinson, G.H., Teo, S. L.-M., \& Rittschof, D. (2011). Biomimetic anchors for antifouling and antibacterial polymer brushes on stainless steel. Langmuir, 27(11), 7065-7076. doi:10.1021/la200620s

Zeitler, V.A., \& Brown, C. A. (1957). The infrared spectra of some Ti-O-Si, Ti-O-Ti and Si-O-Si compounds. The Journal of Physical Chemistry, 61(9), 1174-1177. doi:10.1021/j150555a010

Zhang, M., Oh, J.K., Huang, S.-Y., Lin, Y.-R., Liu, Y., Mannan, M.S., Cisneros-Zevallos, L., \& Akbulut, M. (2015). Priming with nano-aerosolized water and sequential dip-washing with hydrogen peroxide: An efficient 
sanitization method to inactivate Salmonella Typhimurium LT2 on spinach. Journal of Food Engineering, 161(0), 8-15. doi:http://dx.doi.org/10.1016/j.jfoodeng.2015.03.026

Zhang, M., Yang, F., Pasupuleti, S., Oh, J.K., Kohli, N., Lee, I.-S., Perez, K., Verkhoturov, S. V., Schweikert, E.A., Jayaraman, A., Cisneros-Zevallos, L., \& Akbulut, M. (2014). Preventing adhesion of Escherichia coli O157:H7 and Salmonella Typhimurium LT2 on tomato surfaces via ultrathin polyethylene glycol film. International Journal of Food Microbiology, 185(0), 73-81. doi:10.1016/j.ijfoodmicro.2014.05.019

Zhang, X., Wang, L., \& Levänen, E. (2013). Superhydrophobic surfaces for the reduction of bacterial adhesion. RSC Advances, 3(30), 12003. doi:10.1039/c3ra40497h 


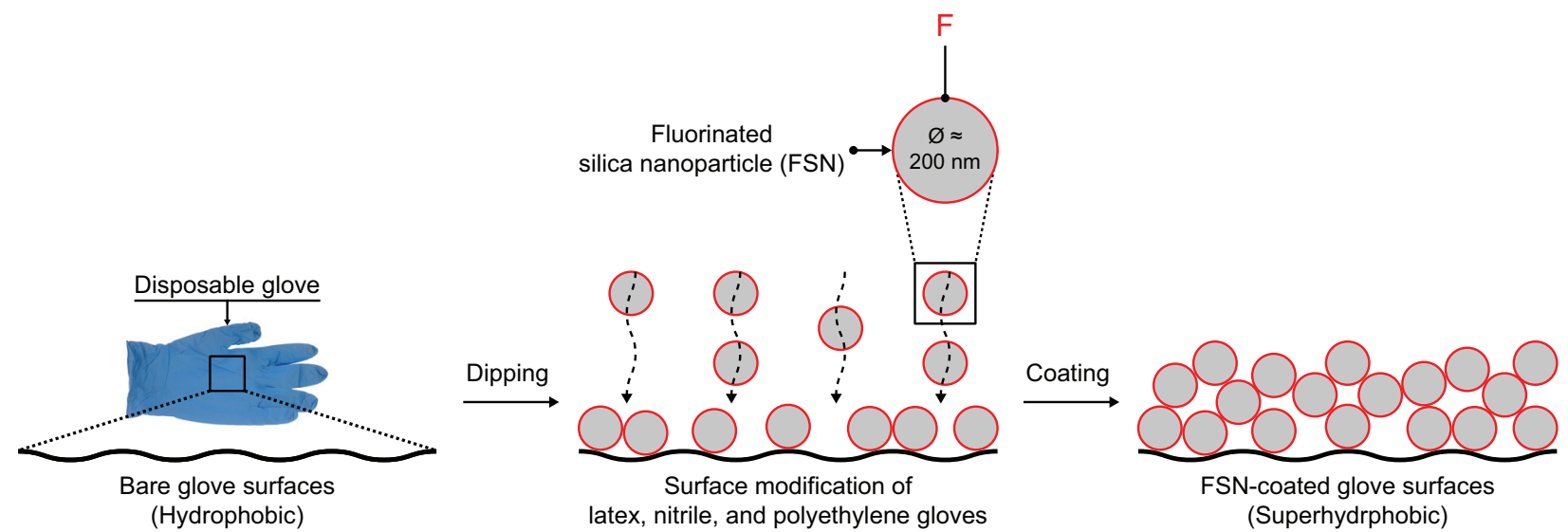

Fig. 1. Schematic illustration of surface modification of disposable gloves with "fluorinated silica nanoparticles" (FSNs) to achieve bacteria-repellent and antiadhesive (antifouling) properties. 

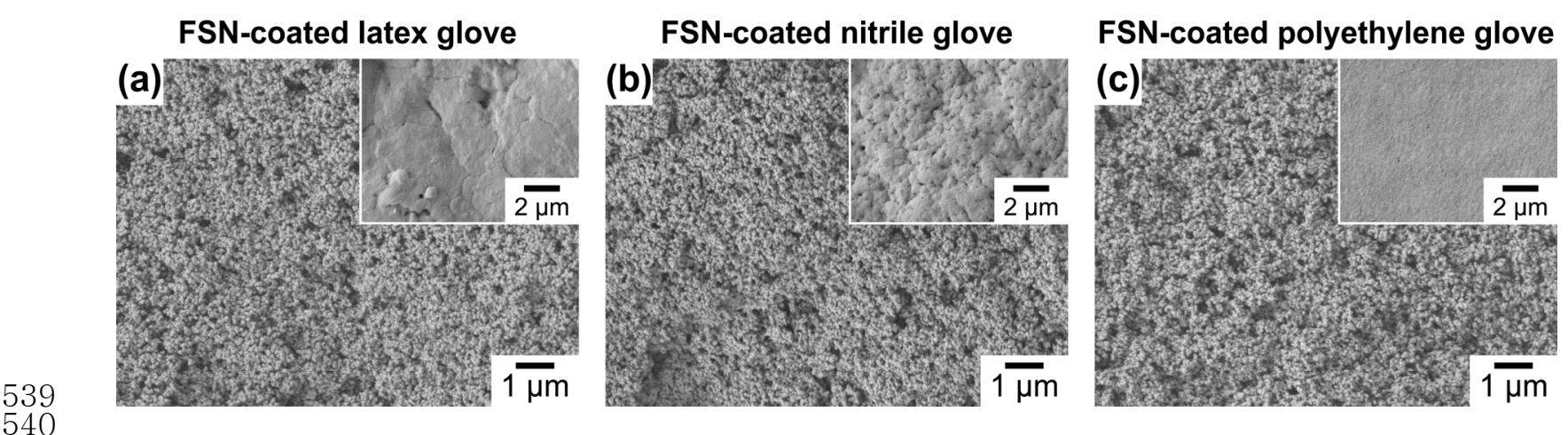

541

Fig. 2. SEM micrographs of FSN-coated (a) latex, (b) nitrile, and (c) polyethylene glove surfaces. Insets: SEM micrographs of bare latex, nitrile, and polyethylene glove surfaces, respectively. 

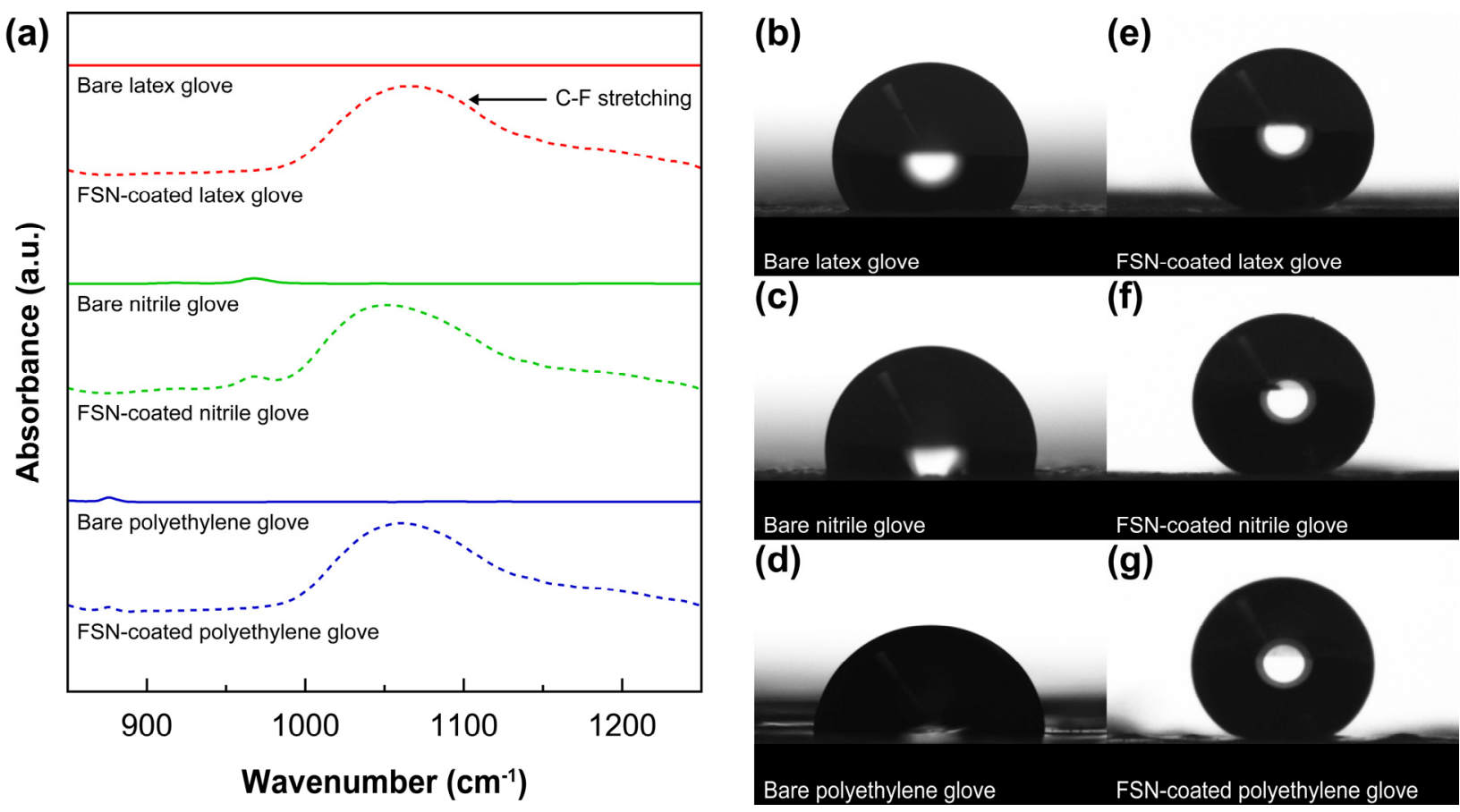

Fig. 3. (a) C-F stretching region from ATR-FTIR spectra of bare and FSN-coated gloves. (b)-(g) The static water 546 contact angle measurements of bare and FSN-coated gloves. 

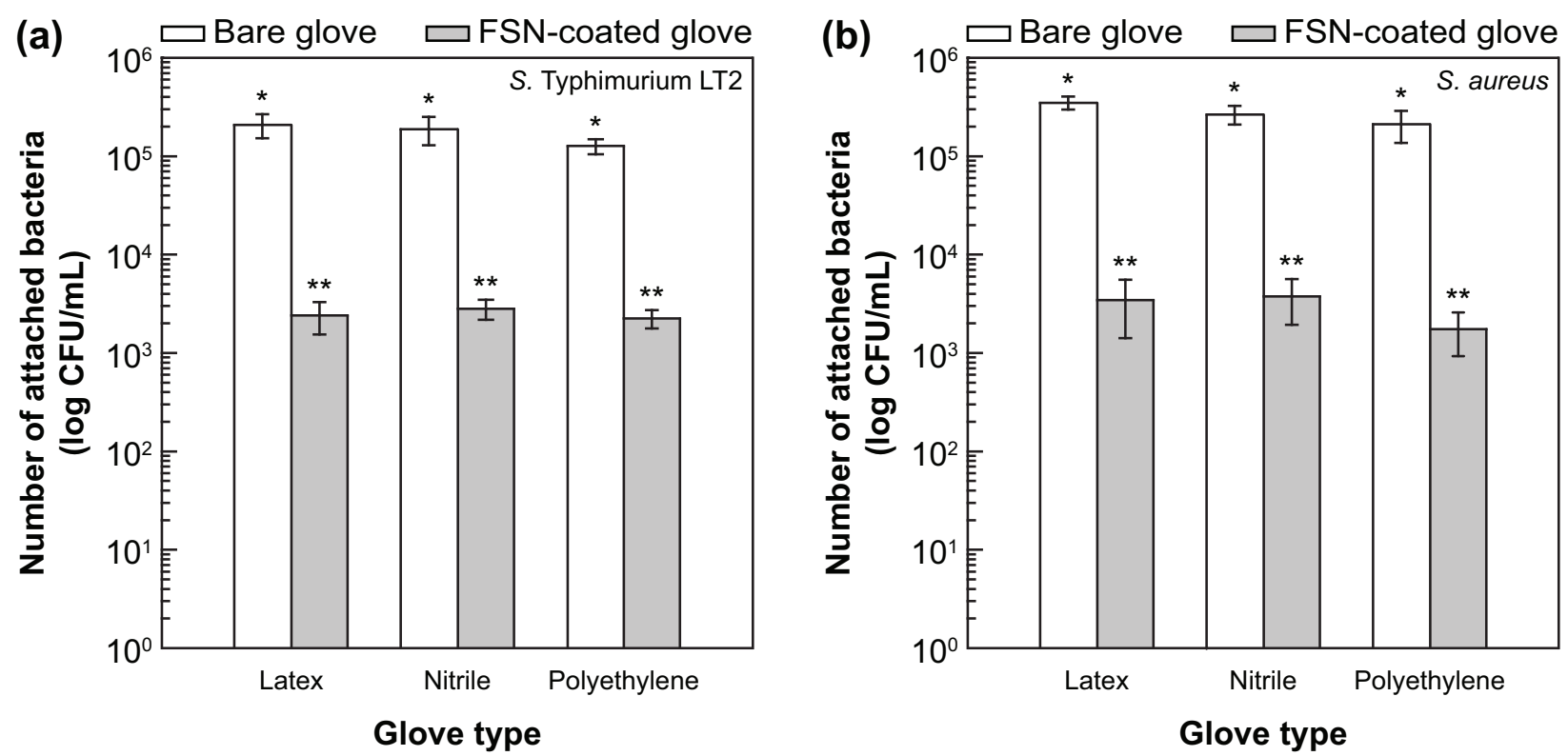

Fig. 4. The comparison of bacterial attachment to bare and FSN-coated gloves for (a) $S$. Typhimurium LT2 and (b) $S$. aureus upon $1 \mathrm{~h}$ exposure to bacteria. The data were obtained by the pour plating method. The number of stars (i.e., $*$ and $* *)$ indicate a statistically significant difference $(p<0.05)$ between bare and FSN-coated gloves. 

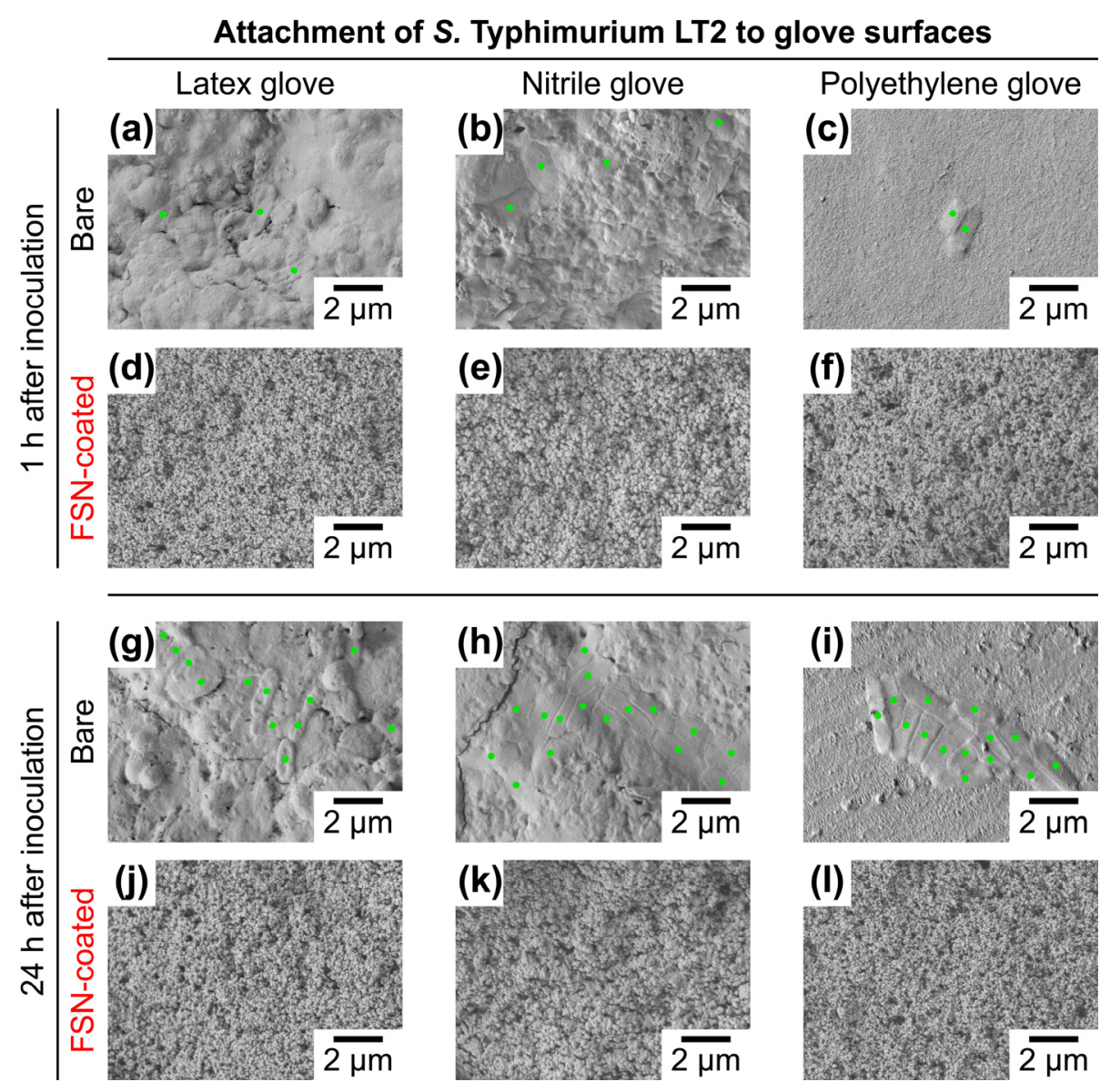

554

Fig. 5. SEM micrographs of attached $S$. Typhimurium LT2 to bare and FSN-coated gloves after (a)-(f) $1 \mathrm{~h}$ and (g)-(l) $24 \mathrm{~h}$ exposure to bacteria. Bacteria on glove surfaces were highlighted with green. 
Attachment of S. aureus to glove surfaces
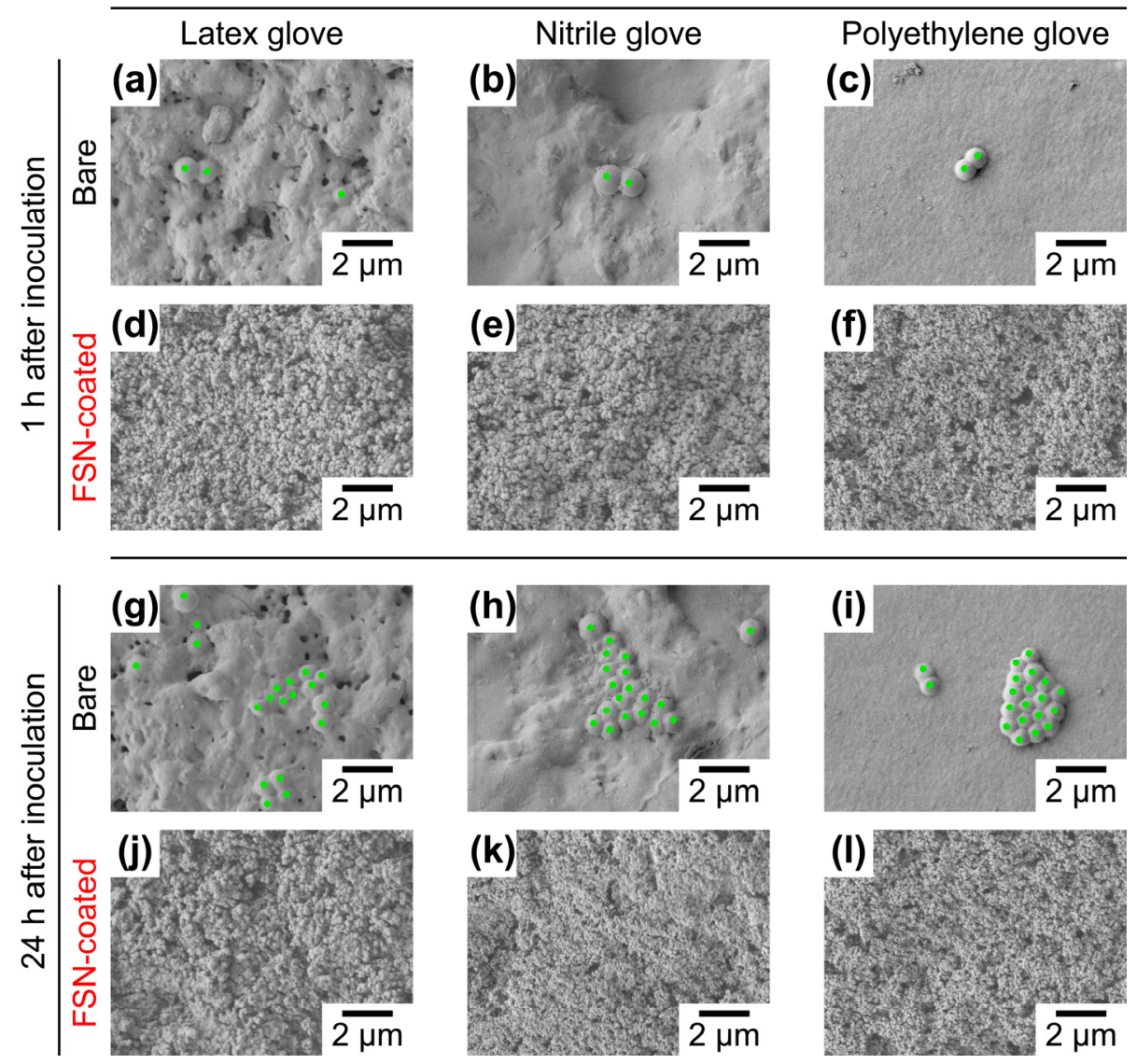

Fig. 6. SEM micrographs of attached S. aureus to bare and FSN-coated gloves after (a)-(f) $1 \mathrm{~h}$ and (g)-(l) $24 \mathrm{~h}$ exposure to bacteria. Bacteria on glove surfaces were highlighted with green. 

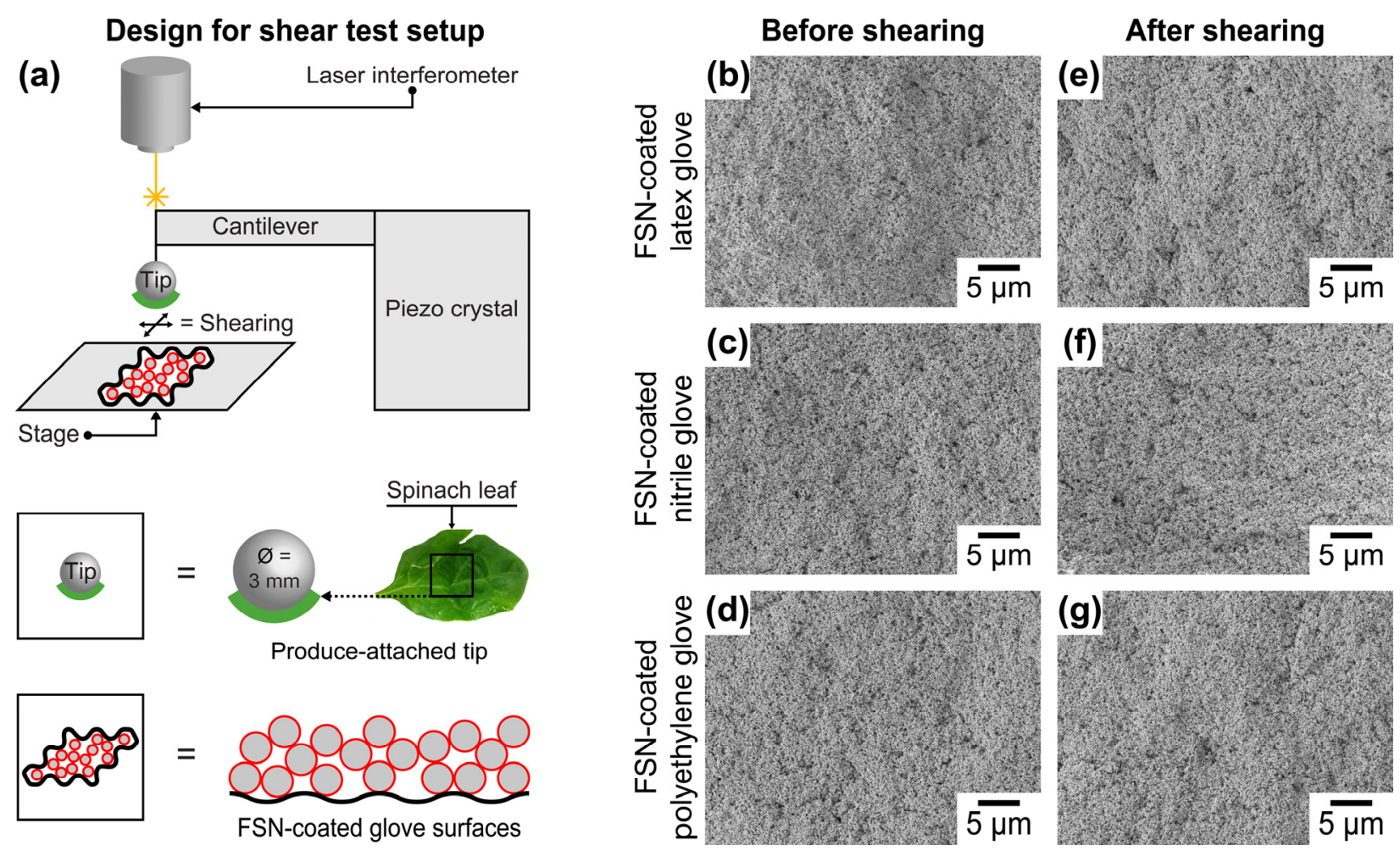

Fig. 7. (a) Schematic drawing of shear test setup to evaluate mechanical durability between produce-attached tip and FSN-coated glove surfaces. SEM micrographs of before (b)-(d) and after (e)-(f) shear test, showing shear resistance of FSN-coated gloves. 


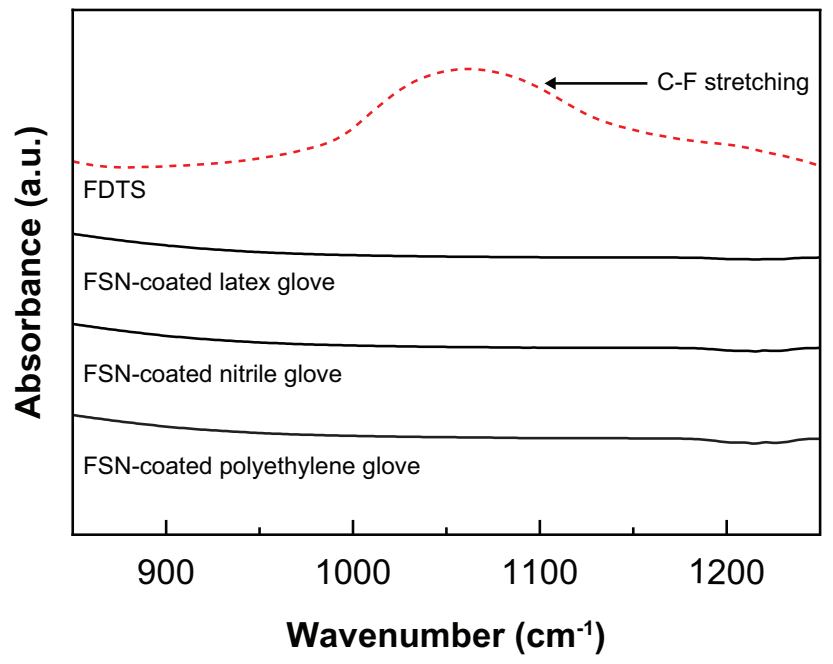

Fig. 8. ATR-FTIR spectra of aliquots collected from the samples (i.e., FSN-coated glove pieces submerged in DI water). The absence of C-F stretching region suggest chemical stability of functional groups on glove surfaces. 